the same as a company doctor? Is it really the same thing to call up a company who is trying to sell you a product and have their doctor, who receives a pay-cheque from them, advise you? To me, it is not the same thing."

The Californian law does not prevent statebased companies from marketing the tests to consumers residing outside the state. But a muddle of different state laws across the United States provides a confusing array of regulations on the issue.

New York's Department of Public Health has sent similar letters to 26 companies since last November. In response, 23 andme and Navigenics have submitted business plans that the department is reviewing, says its spokesman Jeffrey Hammond. "The good news for both 23 andme and Navigenics is the labs they are proposing they use for their lab work are known to the department and have a history of compliance with us." Hammond adds: "Our goal is not to levy fines. It is to bring companies who want to do business in New York into compliance with state law."

Hudson says that the California and New York letters point out the conspicuous lack of unifying federal regulation of genetic testing. The law "is very inconsistent from state to state at a time when the risks to consumers do not vary state to state - and when we have businesses that are certainly operating state to state".

Ryan Phelan, chief executive of DNA Direct, says that the one-size-fits-all approach of the letters is a cause for concern, because tests being offered range from those predicting serious diseases to "fun to know" information with no bearing on a person's health. "There is going to be increasingly a need for nuanced regulation. All genetic tests should not be considered the same."

\title{
Biogen fights takeover bid
}

The latest chapter in the battle over Biogen Idec, a prominent US biotechnology firm, ended last week when shareholders rejected billionaire investor Carl Icahn's bid to oust three members of the company's board of directors. The decision was a clear defeat for Icahn's plan to gain control of the company, which is based in Cambridge, Massachusetts, and a victory in Biogen's struggle to remain independent.

The fight between Icahn (pictured) and Biogen began last August, when Icahn announced that he had acquired $1 \%$ of the company's stock, making him one of its biggest investors. At first, Biogen officials weren't sure what to make of the news, says Naomi Aoki, Biogen's director of public affairs. Icahn is a classic corporate raider, known for gaining control of companies and then forcing them to take actions that increase the value of their stock. Over the past 30 years, Icahn has compelled many of his investments to sell their assets altogether.

"We knew his reputation," says Aoki. "But I don't think it was clear to us right from the beginning how everything would play out."

Icahn's goals fit cleanly with the drug industry's rising demand for biotechnology companies. In April 2007, pharmaceutical giant AstraZeneca surprised analysts by paying US $\$ 15$ billion for MedImmune, a Maryland-based biotechnology company. Icahn, a MedImmune shareholder, later acknowledged that he had pressured
MedImmune's board to sell, and had threatened a hostile takeover if the company did not comply. Biogen, a 30-year-old company with several candidate drugs in the pipeline, is worth $\$ 23$ billion.

In October, Biogen announced that it would accept offers from firms interested in buying the company. It called off the hunt for a purchaser in December, saying that no one had come forward. Icahn accused Biogen of interfering with the search, sued the company for access to records pertaining to the failed sales process, and announced that he was nominating three candidates to the board of directors. It would have been the first step in a two-part plan to gain control of the board that would have been completed next year when four more seats on the 12-member board became available for re-election.

In a memo to shareholders issued two weeks before the vote, Icahn accused Biogen of lying to them about its attempts to sell the company. Biogen issued a letter of its own, saying in bold-faced capital letters: "Do not be misled by Carl Icahn."

On 19 June, a preliminary tally of shareholder votes showed that Biogen had won this round. Icahn has not said what his next move will be, and was not available for comment. But he now controls $4 \%$ of the stock and has said that he has some of the top ten investors on his side, suggesting that Biogen's battles may not be over. Heidi Ledford

\section{Scientists get online news aggregator}

A Canadian graduate student dissatisfied with science coverage on online sites such as Google News and Yahoo News has created a news aggregator especially for scientists.

Michael Imbeault, an HIV researcher at the Université Laval in Quebec, launched his fully automated site called e! Science News (http://esciencenews.com) last month. It has already attracted 300,000 different users, and averages 5,000 visits a day, he says.

News aggregators display headlines and snippets from other media sources, but don't produce their own content. Of the top five online US news sites, three are aggregators - Google News, AOL News and Yahoo News - and only two - CNN.com and MSNBC.com - generate original content. Yahoo and AOL use human editors and source almost all science stories from wire agencies, such as Reuters. Google News uses computer algorithms to aggregate headlines from thousands of news sources, ranking them by how often and on which sites stories appear.
Science and technology coverage on Google News, for example, is notoriously devoid of basic science. Imbeault's site indexes science news sites, clusters similar articles together on the basis of the frequency of word co-occurrence, and then uses Bayesian statistics to automatically assign articles to topics such as astronomy, health and climate. It then ranks them using factors such as timeliness, and the number of sites reporting the same news, which indicates the story's importance. At present, it is limited to around 40 news sources - including Nature News, The New York Times science section and institutional news sites such as NASA, which offer free content for at least a period - but this will be increased, he says.

Imbeault built the site on top of the Drupal open-source content management software. He says that his aggregator will also be improved by moving to semantics-based techniques that better capture the meaning of a text.

Declan Butler 